\title{
PENGARUH KONSENTRASI DAN WAKTU AKTIVASI TERHADAP KARAKTERISTIK KARBON AKTIF AMPAS TEBU DAN FUNGSINYA SEBAGAI ADSORBEN PADA LIMBAH CAIR LABORATORIUM
}

\author{
${ }^{1)}$ Indah Nurhayati, ${ }^{2)}$ Joko Sutrisno, ${ }^{3)}$ Mochamad Sofyan Zainudin \\ 1,2,3 Teknik Lingkungan, FTSP UNIPA Surabaya \\ Email : Indahtekling@yahoo.Com
}

\begin{abstract}
Abstrak
Ampas tebu berpotensi sebagai bahan baku karbon aktif karena mempunyai kadar karbon yang tinggi. Tujuan dari penelitian ini adalah mengkaji pengaruh konsentrasi natrium klorida, dan waktu aktivasi terhadap kualitas karbon aktif ampas tebu dan mengkaji efektifitas karbon aktif ampas tebu sebagai adsorben perak, krom, dan total dissolved solid air limbah laboratorium Teknik Lingkungan Universitas PGRI Adibuana Surabaya. Variabel penelitian adalah konsentrasi natrium klorida 10\%, 12,5\% dan $15 \%$, lama perendaman 12 jam, 18 jam dan 24 jam. Proses adsobsi dilakukan secara kontinyu dengan debit $140 \mathrm{ml} / \mathrm{menit}$ selama 120 menit, analisis sampel dilakukan setiap 15 menit. Hasil dari penelitian ini adalah aktivasi karbon aktif ampas tebu menggunakan larutan natrium klorida $10 \%$ selama 12 jam menghasilkan karbon aktif dengan karakteristik daya serap $\mathrm{I}_{2}$ sebesar $46 \%$, kadar air 1\%, dan kadar abu 7\%, dan sudah sesuai SNI 06-37301995, sedangkan untuk kadar zat yang menguap belum sesuai SNI 06-3730-1995. Selama waktu adsobsi 2 jam karbon aktif ampas tebu, efisiensi penurunan terbaik krom pada menit ke 15 sebesar $8 \%$ dan total dissolved solid sebesar $31 \%$ sedangkan penurunan perak paling tinggi pada menit ke 75 sebesar 24\%. Karakteristik air limbah laboratorium setelah diadsobsi menggunakan karbon aktif ampas tebu, adalah kadar perak $0,71 \mathrm{mg} / \mathrm{L}$, krom $1,12 \mathrm{mg} / \mathrm{L}$, total dissolved solid $15.400 \mathrm{mg} / \mathrm{L}$ dan $\mathrm{pH}$ 1,52, sehingga air limbah belum memenuhi baku mutu sesuai Peraturan Menteri Lingkungan Hidup Republik Indonesia No. 5 Tahun 2014.
\end{abstract}

Kata Kunci : Ampas tebu, limbah cair laboratorium, karbon aktif

\begin{abstract}
Bagasse as raw material for activated carbon because it has high carbon content. The purpose of this research is to study the effect of sodium chloride concentration and activation time on the quality of activated carbon of bagasse and to study the effectiveness of activated carbon of bagasse as silver, chromium, and total dissolved solid waste water of laboratory of Environmental Engineering Universitas PGRI Adibuana Surabaya. The research variables were 10\%, $12.5 \%$ and $15 \%$ sodium chloride concentration, 12 hours, 18 hours and 24 hours immersion time. The absorption was carried out continuously with $140 \mathrm{ml} / \mathrm{min}$ discharge for $120 \mathrm{~min}$, sample analysis was done every $15 \mathrm{~min}$. The result of this research is activation of activated carbon of bagasse using 10\% sodium chloride solution for 12 hours to produce activated carbon with characteristic absorption $I_{2}$ of $46 \%$, moisture content $1 \%$ and ash content $7 \%$, and according to SNI 06-3730-1995, while for the levels of substances that do not evaporate SNI 06-3730-1995. During the 2-hour adsorption period the activated carbon of bagasse, the best chromium reduction efficiency in the $15^{\text {th }}$ minute by $8 \%$ and the total dissolved solids by $31 \%$ while the silver decline was highest at 75 minutes by $24 \%$. Characteristics of laboratory wastewater after adsorption using activated carbon of bagasse is silver

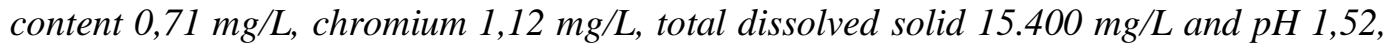


so wastewater not yet fulfill quality standard according to the Minister of Environment Regulation of the Republic of Indonesia No. 5 The year 2014.

Keywords: bagasse, laboratory wastewater, activated carbon

\section{PENDAHULUAN}

Laboratorium Teknik Lingkungan Universitas PGRI Adi Buana (UNIPA) Surabaya merupakan salah satu sarana yang penting sebagai penunjang perkuliahan, penelitian mahasiswa dan dosen. Dalam setiap kegiatan praktikum dan penelitian pasti menghasilkan limbah. Limbah yang dihasilkan dilihat dari kuantitasnya relatif kecil tetapi dilihat dari karakteristiknya termasuk limbah berbahaya dan beracun (B3) karena mengandung logam berat. Karakteristik limbah laboratorium sangat beragam, tergantung jenis praktikum dan penelitian yang dilakukan di laboratorium tersebut.

Laboratorium Teknik Lingkungan UNIPA Surabaya belum pernah dilakukan uji karakteristik limbah cairnya. Air limbah dari kegiatan praktikum dan penelitian di laboratorium Teknk Lingkungan UNIPA Surabaya langsung dibuang ke wastafel tanpa dilakukan pengolahan terlebih dahulu. Dikhawatirkan limbah cair laboratorium tersebut mencemari lingkungan sekitar kampus terutama terhadap badan air dan air tanah.

Limbah laboratorium sangat komplek sifatnya, mengandung senyawa organik dan anorganik, ada yang bersifat asam atau basa, reaktif, iritatif dan mengandung logam yang bersifat racun. Limbah laboratorium termasuk kategori golongan limbah B3. (Hartini, 2011). Limbah laboratorium dapat berasal dari bahan baku yang sudah kadaluarsa, bahan habis pakai, produk proses di laboratorium, produk upaya penanganan limbah, sisa bahan kimia yang selesai digunakan, air bekas cucian peralatan, dan sisa sampel yang diuji.

Bahan yang sering digunakan di laboratorium Teknik Lingkungan UNIPA Surabaya antara lain, bahan yang besifat asam yaitu asam sulfat $\left(\mathrm{H}_{2} \mathrm{SO}_{4}\right)$, asam klorida $(\mathrm{HCl})$, asam asetat $\left(\mathrm{CH}_{3} \mathrm{COOH}\right)$, asam nitrat $\left(\mathrm{HNO}_{3}\right)$, dan lain-lain. Senyawa yang bersifat basa diantaranya natrium hidroksida $(\mathrm{NaOH})$, kalium hidroksida $(\mathrm{KOH})$, amoniak $\left(\mathrm{NH}_{3}\right)$. Senyawa anorganik diantaranya perak nitrat $\left(\mathrm{AgNO}_{3}\right)$, kalium permanganat $\left(\mathrm{KMnO}_{4}\right)$, kalium kromat $\left(\mathrm{KCrO}_{4}\right)$, kalium bikromat $\left(\mathrm{K}_{2} \mathrm{Cr}_{2} \mathrm{O}_{7}\right)$, tembaga sulfat $\left(\mathrm{CuSO}_{4}\right)$, timbal nitrat $\left(\mathrm{Pb}\left(\mathrm{NO}_{3}\right)_{2}\right.$, natrium klorida $(\mathrm{NaCl})$

Karbon aktif adalah karbon yang diaktifkan secara fisika, kimia atau fisikkimia. Karbon aktif dapat berbentuk granul atau serbuk, serta mempunyai kemampuan daya jerap yang baik. Karbon aktif digunakan sebagai bahan pemucat (penghilang zat warna), penyerap gas, penyerap logam, dan sebagainya. (Asbahani, 2013)

Karakteristik bahan baku dan metode aktivasi sangat mempengaruhi kualitas karbon aktif yang dihasilkan. Aktivasi secara kimia sering menggunakan aktivator $\mathrm{KOH}, \mathrm{NaOH}$, $\mathrm{ZnCl}_{2}, \mathrm{NaCl}, \mathrm{Na}_{2} \mathrm{CO}_{3}, \mathrm{HCl}, \mathrm{H}_{2} \mathrm{SO}_{4}$, $\mathrm{H}_{3} \mathrm{PO}_{4}$, dan lain-lain (Patil dan Kulkarni, 2012).

$\mathrm{NaCl}$ merupakan aktivator yang efektif karena mudah didapat, harganya lebih ekonomis, tidak berbahaya dan tidak beracun. Mirwan (2005) pada pembuatan karbon aktif dari ampas tebu dengan aktivator $\mathrm{NaCl} 15 \%$ dan lama perendaman 10 jam menghasilkan karbon aktif yang sifatnya serupa dengan karbon aktif yang diaktivasi dengan larutan $\mathrm{H}_{3} \mathrm{PO}_{4}$. Aktivasi kimia menggunakan larutan $\mathrm{NaCl}$ yang dilanjutkan dengan aktivasi fisik pada suhu $\quad 700^{\circ} \mathrm{C}$ terbukti efektif menghasilkan karbon aktif dari limbah serutan rotan dengan karakteristik fisik- 
kimia yang memenuhi SNI 06-3730-95 (Mizwar, 2014)

Ampas tebu adalah limbah yang dihasilkan dari industri gula maupun pembuatan minuman dari air tebu. Es tebu saat ini banyak digemari oleh masyarakat karena harganya terjangkau dan rasanya yang nikmat. Ampas tebu belum dimanfaatkan secara optimal sehingga membawa masalah bagi industri gula dan lingkungan karena dianggap sebagai limbah (Nurhayati, 2014). Industri gula rata-rata menghasilkan ampas tebu sebesar 32\% dari bobot tebu yang digiling. Ampas tebu sebagian besar digunakan sebagai bahan bakar boiler dan sekitar 1,6\% dari bobot ampas tebu tidak dimanfaatkan Ampas tebu mengandung bahan organik sekitar 90\%, sehingga berpotensi untuk dijadikan bahan baku karbon aktif (Nurhayati, 2015)

Ampas tebu dapat berfungsi sebagai adsorben logam berat seperti yang dikemukakan oleh Nurhayati (2014) bahwa ampas tebu dapat mengadsobsi logam $\mathrm{Cu}(\mathrm{II})$ sebesar $94,3 \%$ pada $\mathrm{pH}$ 6,5. Menurut Nurhayati (2015) bahwa karbon aktif dari ampas tebu dengan suhu pembakaran $350^{\circ} \mathrm{C}$ dan diaktivasi menggunakan $\mathrm{CaCO}_{3}$ 5,5.10-5 $\mathrm{M}$ menghasilkan karbon aktif yang kualitasnya sesuai SNI 06-37301995 terutama untuk parameter kadar air dan daya serap iodium $\left(\mathrm{I}_{2}\right)$. Karbon aktif sebagai media filtrasi dapat menurunkan Fe sebesar $88 \%$ dan kesadahan $60 \%$.

Beberapa metode untuk menghilangkan logam berat dari air limbah telah dilakukan dengan proses secara fisika dan kimia yang meliputi presipitasi, koagulasi, dan pertukaran ion, ekstraksi pelarut, ekstraksi elektrolisis, penguapan, osmosis, pertukaran ion dan adsorpsi (Priadi, 2014), tetapi metode-metode tesebut relatif mahal. Proses adsorpsi merupakan teknik pemurnian dan pemisahan yang efektif dipakai karena lebih ekonomis dalam pengolahan air dan limbah. Proses adsorbsi cocok untuk air limbah dengan konsentrasi logam rendah dan industri dengan keterbatasan biaya (Yuan dan Liu, 2013).

Tujuan dari penelitian ini adalah : (1) Menentukan konsentrasi aktivator $\mathrm{NaCl}$ dan waktu aktivasi yang menghasilkan karbon aktif ampas tebu paling berkualitas. Kualitas karbon aktif mengacu pada SNI 06-3730-1995. (2) Mengkaji efektifitas karbon aktif ampas tebu sebagai adsorben $\mathrm{Cr}, \mathrm{Ag}$, dan Total Dissolved Solid (TDS pada limbah cair laboratorium Teknik Lingkungan UNIPA Surabaya.

\section{METODE}

Langkah penelitian yang dilakukan adalah:

\section{Persiapan Alat dan Bahan}

Proses adsopsi dilakukan menggunakan pipa paralon diameter 3" dan panjang $100 \mathrm{~cm}$, dengan media adsopsi tambahan kerikil dan pasir. Sebelum digunakan media dicuci dengan aquadest sampai bersih dan dikeringkan sampai benar-benar kering dengan sinar matahari.

\section{Pembuatan Karbon Ampas Tebu}

Ampas tebu yang berasal dari penjual es tebu dipotong dengan ukuran sekitas $(10-15 \mathrm{~mm})$ supaya homogeny ukuranya, lalu dicuci dengan aquadest dan dikeringkan dengan sinar matahari sampai kering. Kemudian dibakar dalam furnance selama 45 menit pada suhu $350^{\circ} \mathrm{C}$. Proses aktivasi karbon ampas tebu dilakukan dengan cara direndam dalam larutan $\mathrm{NaCl}$ yang divariasikan $(10 \%, 12.5 \%$, dan $15 \%)$ pada suhu $80^{\circ} \mathrm{C}$ selama 4 jam dan perendaman dilanjutkan pada suhu kamar selama waktu yang divariasikan (12 jam, 18 jam, dan 24 jam). Karbon disaring dengan kertas saring, dan dicuci dengan aquadest hingga $\mathrm{pH}$ 7. Karbon aktif dikeringkan dalam oven dari suhu kamar sampai suhu $200^{\circ} \mathrm{C}$ selama 2 jam.

\section{Analisis Karakteristik Karbon Aktif}

Kualitas karbon aktif yang dianalisis adalah bagian yang hilang pada pemanasan $950^{\circ} \mathrm{C}$, kadar air, kadar 
Indah Nurhayati, Joko Sutrisno, \& Mochamad Sofyan Zainudin : Pengaruh Konsentrasi Dan Waktu Aktivasi Terhadap Karakteristik Karbon Aktif Ampas Tebu Dan Fungsinya Sebagai Adsorben Pada Limbah Cair Laboratorium

abu, dan daya serap $\mathrm{I}_{2}$.

\section{Adsopsi Limbah Cair}

Proses adsopsi dilakukan dalam skala laboratorium dengan sistem kontinyu selama 120 menit dan pengambilan sampel dilakukan setiap 15 menit. Parameter yang dianalisis adalah $\mathrm{Ag}, \mathrm{Cr}, \mathrm{pH}$ dan TDS. Analisi $\mathrm{Ag}$ dan $\mathrm{Cr}$ menggunakan AAS, TDS menggunakan gravimetri dan $\mathrm{pH}$ menggunakan $\mathrm{pH}$ meter

\section{HASIL DAN PEMBAHASAN}

Pengaruh Lama Aktivasi dan Konsentrasi NaCl Terhadap Karakteristk Karbon Aktif

Kualitas karbon aktif ampas tebu yang diaktivasi dengan $\mathrm{NaCl}$ dapat dilihat pada Tabel 1 .

Tabel 1. Karakteristik Karbon Aktif Ampas Tebu

\begin{tabular}{cccccccccc}
\hline Aktivator & $\begin{array}{c}\text { waktu } \\
\text { aktivasi } \\
\text { (jam) }\end{array}$ & $\begin{array}{c}\text { Kadar air } \\
(\%)\end{array}$ & $\begin{array}{c}\text { ket } \\
\text { Kadar } \\
\text { abu } \\
(\%)\end{array}$ & ket & $\begin{array}{c}\text { Kadar zat yg } \\
\text { menguap }(\%)\end{array}$ & Ket & $\begin{array}{c}\text { daya } \\
\text { serap } \\
\mathrm{I}_{2}(\%)\end{array}$ & Ket \\
$\mathrm{NaCl}$ & 12 & 1 & $\mathrm{M}$ & 7 & $\mathrm{M}$ & 71 & $\mathrm{TM}$ & 46 & $\mathrm{M}$ \\
$10 \%$ & 18 & 1 & $\mathrm{M}$ & 10 & $\mathrm{M}$ & 83 & $\mathrm{TM}$ & 45 & $\mathrm{M}$ \\
& 24 & 2 & $\mathrm{M}$ & 11 & $\mathrm{M}$ & 93 & $\mathrm{TM}$ & 43 & $\mathrm{M}$ \\
$\mathrm{NaCl}$ & 12 & 2 & $\mathrm{M}$ & 10 & $\mathrm{M}$ & 66 & $\mathrm{TM}$ & 44 & $\mathrm{M}$ \\
$12.5 \%$ & 18 & 2 & $\mathrm{M}$ & 13 & $\mathrm{TM}$ & 72 & $\mathrm{TM}$ & 44 & $\mathrm{M}$ \\
& 24 & 3 & $\mathrm{M}$ & 16 & $\mathrm{TM}$ & 80 & $\mathrm{TM}$ & 43 & $\mathrm{M}$ \\
$\mathrm{NaCl}$ & 12 & 2 & $\mathrm{M}$ & 23 & $\mathrm{TM}$ & 65 & $\mathrm{TM}$ & 43 & $\mathrm{M}$ \\
$15 \%$ & 18 & 3 & $\mathrm{M}$ & 26 & $\mathrm{TM}$ & 71 & $\mathrm{TM}$ & 41 & $\mathrm{M}$ \\
& 24 & 4 & $\mathrm{M}$ & 27 & $\mathrm{TM}$ & 73 & $\mathrm{TM}$ & 38 & $\mathrm{M}$ \\
$\mathrm{Rerata}$ & & 2.2 & & 15.9 & & 74.9 & & 43 & \\
\hline
\end{tabular}

Ket :

M : Memenuhi SNI 06-3730-1995

TM : Tidak memenuhi SNI 06-3730-1995

Daya Serap Terhadap Iodium $\left(\mathbf{I}_{2}\right)$

Daya serap karbon aktif terhadap $\mathrm{I}_{2}$ adalah jumlah miligram iodium yang diadsorpsi oleh satu gram karbon aktif (Nurhayati, 2015). Daya serap $\mathrm{I}_{2}$ menunjukan indikator relatif porositas karbon aktif (Collin et al., 2006). Besar kecilnya nilai daya serap terhadap $\mathrm{I}_{2}$ karbon aktif menunjukan kemampuan adsorben dalam mengadsorpsi logam, penghilangan bau, rasa dll. Hasil analisa pengaruh waktu aktivasi dan konsentrasi $\mathrm{NaCl}$ terhadap daya serap $\mathrm{I}_{2}$ dapat dilihat pada Gambar 1.

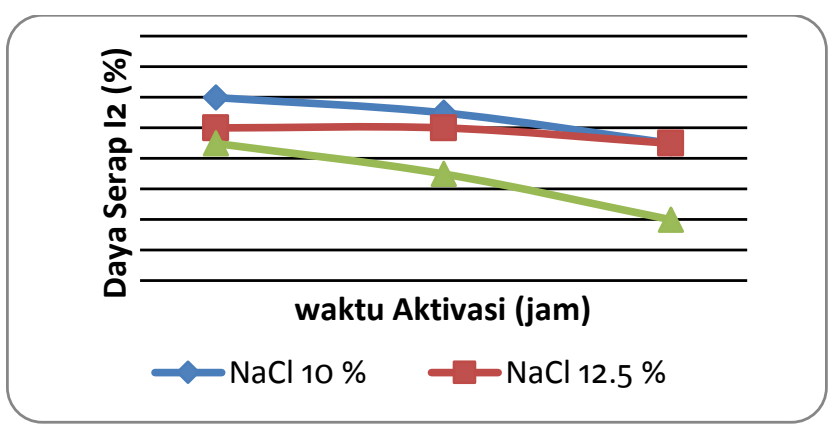

Gambar 1. Pengaruh Waktu Aktivasi dan Konsentrasi NaCl Terhadap Daya Serap $\mathrm{I}_{2}$ 
Berdasarkan Gambar 1 dapat dilihat bahwa waktu aktivasi dan konsentrasi $\mathrm{NaCl}$ berbanding terbalik terhadap terhadap daya serap $\mathrm{I}_{2}$. Semakin lama dari waktu aktivasi dari 12 jam - 24 jam dan semakin pekat konsentrasi $\mathrm{NaCl}$ dari $10 \%$ - $15 \%$, semakin kecil daya serap $\mathrm{I}_{2}$. Hal ini terjadi karena pada waktu aktivasi yang cepat pada konsentrasi rendah, menyebabkan $\mathrm{NaCl}$ terdistribusi secara merata dengan dispersi tinggi di seluruh bagian dalam partikel sehingga menghasilkan pori yang seragam (Verla et al., 2012). Semakin pekat konsentrasi $\mathrm{NaCl}$ semakin banyak mineral yang teradsorpsi sehingga menyebabkan volume pori karbon aktif cenderung bertambah besar karena garam dapat berfungsi sebagai dehydrating agent dan membantu menghilangkan endapan hidrokarbon yang dihasilkan pada proses karbonisasi. Angka $I_{2}$ cenderung bertambah besar dan penambahan bahan - bahan mineral akan melindungi permukaan karbon aktif sehingga bahaya oksidasi karbon menjadi tertekan (Widayanti, 2012). Hasil penelitian ini sejalan dengan hasil penelitian Mizwar (2014) bahwa waktu aktivasi dan konsentrasi aktivator berbanding terbalik dengan daya serap $\mathrm{I}_{2}$.

Daya serap karbon aktif yang dihasilkan berkisar antara $43 \%-46 \%$. Daya serap $\mathrm{I}_{2}$ paling besar adalah $46 \%$ diperoleh pada aktivasi $\mathrm{NaCl} 10 \%$ selama 12 jam. Menurut standart kualitas karbon aktif SNI 06-3730-1995 daya serap $\mathrm{I}_{2}$ adalah minimal $20 \%$, dengan demikian karbon aktif ampas tebu dengan aktivasi $\mathrm{NaCl} 10 \%, 12.5 \%$, dan $15 \%$ dan selama 12 jam, 18 jam, dan 24 jam sudah memenuhi kualitas sesuai SNI 06-3730-1995 untuk parameter daya serap $I_{2}$. Dari hasil penelitian ini menunjukan bahwa proses karbonasi dan aktivasi dapat meningkatkan porositas karbon aktif.

\section{Kadar Air}

2.

Kadar air karbon aktif ampas tebu dengan aktivator $\mathrm{NaCl}$ disajikan dalam Gambar

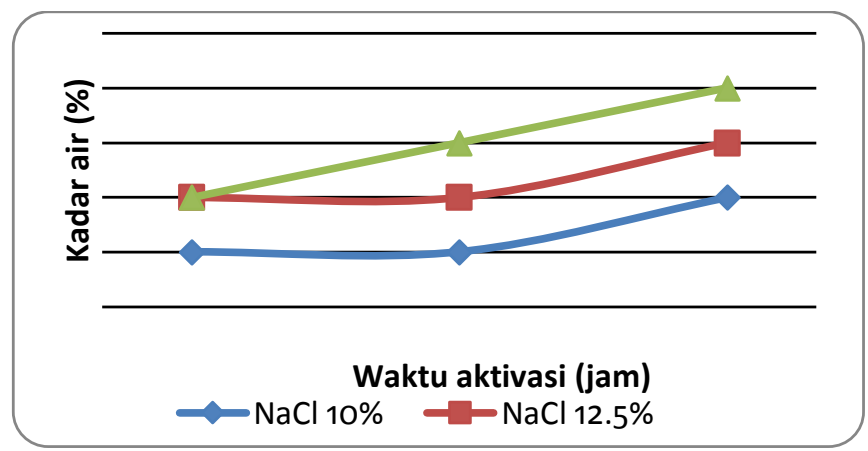

Gambar 2. Pengaruh Waktu Aktivasi dan Konsentrasi NaCl Terhadap Kadar Air

Pada Gambar 2 menunjukkan peningkatan kadar air pada karbon aktif berbanding lurus dengan peningkatan konsentrasi $\mathrm{NaCl}$ dan lama waktu perendaman. Semakin lama waktu aktivasi, kadar air yang terkandung di dalam karbon aktif meningkat. Hal ini dikarenakan semakin lama aktivasi semakin banyak kandungan air yang teserap karbon aktif (Surest, 2010).

Dari hasil penelitian ini diperoleh karbon aktif dengan kadar air berkisar $1 \%$ - 4\%. Kadar air terbaik diperoleh pada aktivasi dengan $\mathrm{NaCl} 10 \%$ selama 12 jam. Sesuai dengan SNI 06-37301995 kadar air untuk karbon aktif serbuk maksimal 15\%. dengan demikian karbon 
aktif ampas tebu dengan konsentrasi $\mathrm{NaCl} 10 \%, 12.5 \%$, dan $15 \%$ dan aktivasi selama 12 jam, 18 jam, dan 24 jam dihasilkan karbon aktif yang memenuhi kualitas kadar air.

Pada Gambar 2 dapat dilihat bahwa semakin tinggi konsenrasi $\mathrm{NaCl}$ juga menyebabkan semakin kadar air dari karbon aktif, hal ini dimungkinkan masih terdapat $\mathrm{NaCl}$ di luar pori karbon sehingga menyebabkan meningkatnya kadar air karbon aktif tersebut karena $\mathrm{NaCl}$ bersifat higroskopis. Hasil penelitian ini sejalan dengan hasil penelitian Mizwar (2014), peningkatan kadar air pada karbon aktif berbanding lurus dengan peningkatan konsentrasi $\mathrm{NaCl}$ dan lama waktu perendaman

\section{Kadar Abu}

Kadar abu merupakan persentase abu yang dihasilkan dari pembakaran sempurna dari suatu bahan organik. Kandungan abu berupa bahan organik maupun mineral yang tidak dapat dibakar atau sisa yang tetap tertinggal setelah pembakaran, misalnya silika dan oksida. Penentuan kadar abu bertujuan untuk mengetahui jumlah oksida yang terkandung dalam karbon aktif (Surest, 2010).

Hasil analisa dari uji kadar abu dapat dilihat pada Gambar 3. Hasil penelitian ini menunjukkan bahwa semakin tinggi konsentrasi $\mathrm{NaCl}$ dari $10 \%-15 \%$ dan semakin lama waktu aktivasi dari 12 jam - 24 jam maka kadar abu karbon aktif semakin meningkat. Hal ini disebabkan karena semakin besar konsentrasi $\mathrm{NaCl}$ dan semakin lama waktu aktivasi maka semakin besar pula mineral tertinggal dalam karbon aktif. Pada proses pencucian tidak dapat memastikan hilangnya mineral secara keseluruhan. Makin tinggi mineral yang tertangkap dalam pori-pori karbon aktif menyebabkan semakin tinggi pula kadar oksidanya sehingga kadar abu juga semakin tinggi (Surest, 2010).

Kadar abu karbon aktif yang dihasilkan sekitar antara $7 \%$ - $27 \%$. Aktivasi menggunakan $\mathrm{NaCl} \quad 10 \%$ dengan waktu aktivasi 12 jam - 24 jam menghasilkan karbon aktif yang sesuai SNI 06-3730-1995. Sedangkan aktivasi menggunakan $\mathrm{NaCl}$ dengan konsentrasi diatas $10 \%$ kadar abunya tidak sesuai SNI 06-3730-1995.

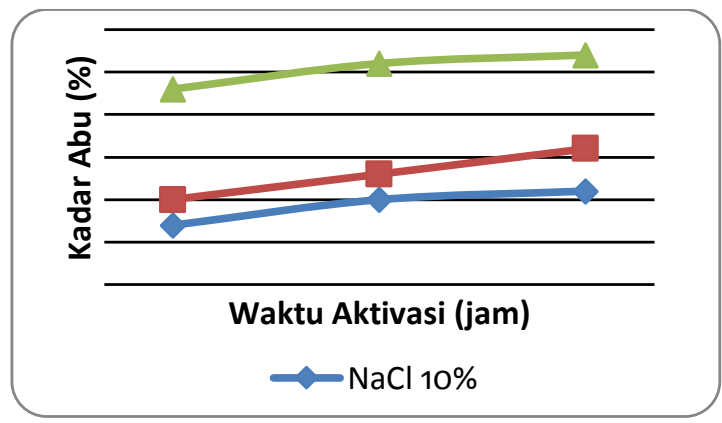

Gambar 3. Pengaruh Lama Aktivasi dan Konsentrasi NaCl Terhadap Kadar Abu

\section{Bagian Yang Hilang Pada Pemanasan $950^{\circ} \mathrm{C}$}

Sesuai dengan SNI 06-3730-1995 bahwa karbon aktif kadar bagian yang hilang pada pemanasan $950^{\circ} \mathrm{C}$ maksimal 25\%. Karbon aktif yang dihasilkan dalam penelitian ini mempunya kadar bagian yang hilang pada pemanasan $950^{\circ} \mathrm{C}$ antara $71 \%$ - $73 \%$. Secara keseleruhan karbon aktif yang dihasilkan belum memenuhi SNI 06-3730-1995. Hal ini kemungkinan karbon aktif dari ampas tebu memiliki struktur yang lunak sehingga pada pemanasan $950^{\circ} \mathrm{C}$ mudah terbakar. Menurut Nurhayati (2015) bahwa karbon aktif yang belum memenuhi standar karbon aktif sesuai SNI 06-3730-1995 disebabkan tidak 
sempurnanya penguraian senyawa non karbon seperti $\mathrm{CO}_{2}, \mathrm{CO}$ dan $\mathrm{H}_{2}$. hilang pada pemanasan $950^{\circ} \mathrm{C}$ dapat dilihat pada Gambar 4.

Hasil analisa dari uji bagian yang

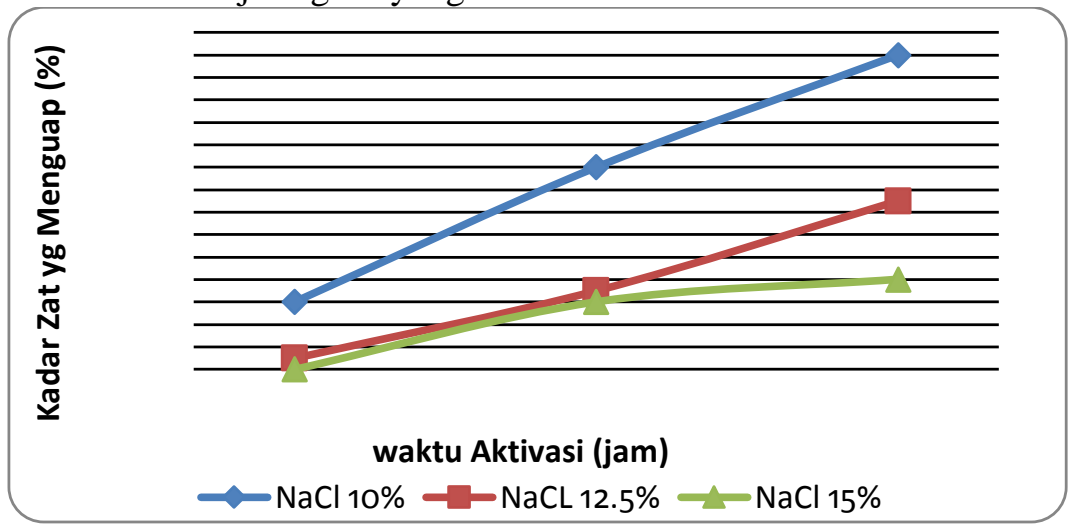

Gambar 4. Pengaruh Lama Aktivasi dan Konsentrasi NaCl Terhadap

Kadar Bagian Yang Hilang Pada Pemanasan $950^{\circ} \mathrm{C}$

Pada Gambar 4 menunjukan bahwa semakin lama waktu aktivasi dan semakin tinggi konsentrasi $\mathrm{NaCl}$, semakin tinggi pula kadar bagian yang hilang pada pemanasan $950^{\circ} \mathrm{C}$. keadaan ini dikarenakan pada semakin lama waktu perendaman dan semakin tinggi konsentrasi $\mathrm{NaCl}$ menyebabkan tidak sempurnanya penguraian senyawa non karbon yang ada di dalam ampas tebu.

Pada penelitian ini karbon aktif yang terbaik diperoelh pada aktivasi menggunakan $\mathrm{NaCl} 10 \%$ selama 12 jam dengan karakteristik karbon aktif adalah kadar air $1 \%$., kadar abu $7 \%$ daya serap $\mathrm{I}_{2} 46 \%$.

Karbon aktif ampas tebu dengan aktivasi $\mathrm{NaCl} 10 \%$ selama 12 jam selanjutnay digunakan untuk mengadsorpsi logam berat $\mathrm{Ag}, \mathrm{Cr}$, dan TDS yang ada pada limbah cair laboratorium Teknik Lingkungan Universitas PGRI Adi Buana Surabaya.

\section{Adsopsi Limbah Cair Laboratorium Menggunakan Karbon Aktif Ampas Tebu}

Air limbah laboratorium Teknik Lingkungan UNIPA Surabaya sebelum ditreatment secara fisik berwarna hijau, keruh, dan berbau. Karakteristik limbah cair laboratorium Teknik Lingkungan UNIPA Surabaya adalah sebagai berikut, $\mathrm{Ag}=0,94 \mathrm{ppm}, \mathrm{Cr}=1,22 \mathrm{ppm}$, TDS $22.400 \mathrm{ppm}$ dan $\mathrm{PH}=0,4$. Dilihat dari karakteristiknya limbah cair laboratorium Teknik Lingkungan UNIPA Surabaya termasuk limbah B3 dan belum memenuhi baku mutu air limbah sesuai dengan Peraturan Menteri Lingkungan Hidup No. 5 Tahun 2014.

Setelah diadsobsi menggunakan karbon aktif ampas tebu yang diaktivasi menggunaka $\mathrm{NaCl} 10 \%$ selama 12 jam menghasilkan air limbah yang jernih, berwarna hijau dan baunya sedikit berkurang. Efisiensi penurunan TDS, $\mathrm{Ag}$ dan $\mathrm{Cr}$ air limbah disajikan dalam Gambar 5. 


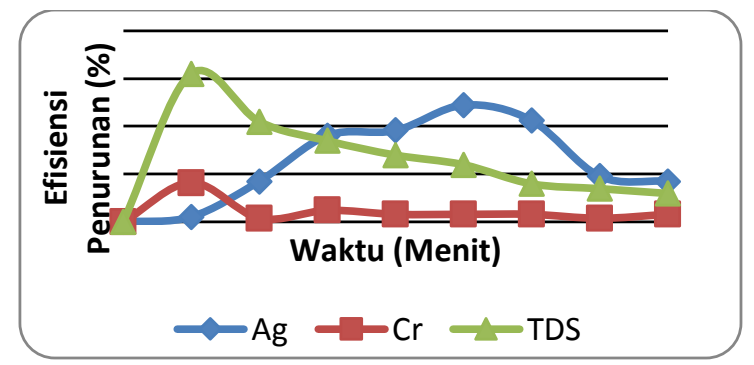

Gambar 5. Efisiensi Penurunan TDS, Ag dan $\mathrm{Cr}$

Dari Gambar 5 dapat dilihat bahwa efisiensi penurunan $\mathrm{Ag}$ paling baik sebesar $24 \%$ dengan kadar akhir $0.71 \mathrm{ppm}$, terjadi pada menit ke 75 . Di atas menit ke 75 efisiensi penurunan $\mathrm{Ag}$ mengalami penurunan. Efisiensi penurunan kadar $\mathrm{Cr}$ dan TDS tertinggi terjadi pada menit ke-15 sebsar 8\% dengan kadar $8.2 \mathrm{ppm}$ dan TDS $31 \%$ dengan kadar 15.400 ppm pada menit ke-15. Di atas menit ke-15 efisiensi penurunan $\mathrm{Cr}$ cenderung konstan sedangkan efisiensi penurunan TDS mengalami penurunan. Terjadinya penurunan efisiensi karena adsorben sudah jenuh, sehingga kapasitas adsorpsi menurun. Pada saat mengalami penurunan efisiensi berarti adsorben harus diregenerasi. Hal ini dikarenakan pada mulanya sisi adsorben banyak yang kosong, sehingga kecenderungan adsorbat untuk terserap ke adsorben semakin besar. Dengan semakin lamanya waktu kontak, jumlah adsorbat yang terserap permukaan adsorben semakin meningkat sehingga tercapai titik setimbang (Sari, 2010). Pada saat titik kesetimbangan tercapai maka permukaan adsorben sudah dipenuhi oleh adsorbat, jika larutan terlalu tinggi mengandung adsorbat maka adsorben mengalami titik jenuh sehingga adsorben tidak mampu mengadsorpsi lagi.

Pada penilitian ini adsorpsi yang terjadi adalah adsorpsi fisik dimana tidak terjadi transfer elektron. Adsorpsi fisika terjadi bila gaya intermolekular lebih besar dari gaya tarik antar molekul atau gaya tarik menarik yang relatif lemah antara adsorbat dengan permukaan adsorben, gaya ini disebut gaya Van der Waals sehingga adsorbat dapat bergerak dari satu bagian permukaan lain dari adsorben (Sari, 2010).

Dengan proses adsobsi menggunakan karbon aktif ampas tebu hanya dapat menaikan $\mathrm{pH}$ pada 15 menit pertama dan kenaikan pHnya hanya 28\%. Kualitas air limbah Laboratorium Teknik Lingkungan UNIPA Surabaya setelah diadsopsi menggunakan karbon aktif ampas tebu yang diaktivasi dengan $\mathrm{NaCl} 10 \%$ selama 12 jam, adalah kadar Ag sebesar $0,71 \mathrm{mg} / \mathrm{L}, \mathrm{Cr}$ seesar $1,12 \mathrm{mg} / \mathrm{L}$, TDS sebesar $15.400 \mathrm{mg} / \mathrm{L}$ dan $\mathrm{pH}$ 1,52. Dari parameter tersebut menunjukan air limbah belum memenuhi baku mutu sesuai dengan Peraturan Menteri Lingkungan Hidup No. 5 tahun 2014 tentang baku mutu air limbah bagi usaha dan/atau kegiatan yang belum memiliki baku mutu air limbah yang ditetapkan.

Proses adsopsi menggunakan karbon aktif ampas tebu efisiensinya rendah dan karakteristik limbahnya belum memenuhi baku mutu, hal ini dkarenakan $\mathrm{pH}$ limbah sangat asam sehingga proses adsopsi tidak dapat optimal. Menurut Handayani (2012) bahwa kemampuan adsobsi ion logam juga dipengaruhi oleh $\mathrm{pH}$ karena adanya protonasi gugus anionik. Pada $\mathrm{pH}$ rendah konsentrasi ion $\mathrm{H}^{+}$menjadi sangat tinggi sehingga terjadi tolak menolak atau kompetisi antara ion $\mathrm{H}^{+}$ dengan ion logam terhadap situs petukaran kation yang bermuatan positif, sehingga adsobsi menjadi kecil. Adsobsi logam akan mengalami 
peningkatan dengan naiknya $\mathrm{pH}$ dan pada $\mathrm{pH}$ tertentu yang lebih tinggi justru mengalami penurunan akibat terbentuknya endapan logam hidroksida.

\section{KESIMPULAN}

Dari penelitian tentang pengaruh konsenrtrasi $\mathrm{NaCl}$ dan waktu aktivasi terhadap kualitas karbon aktif dan fungsinya sebagai adsorben limbah cair laboratorium Teknik Lingkungan UNIPA Surabaya disimpulkan bahwa: (1) aktivasi karbon aktif ampas tebu menggunakan $\mathrm{NaCl} 10 \%$ selama 12 jam menghasilkan karbon aktif ampas tebu dengan kualitas yang paling baik yaitu daya serap $\mathrm{I}_{2}$ sebesar $46 \%$, kadar air $1 \%$, dan kadar abu 7\%, sehingga sesuai SNI 06-3730-1995, (2) selama 2 jam proses adsobsi, efisiensi penurunan terbaik $\mathrm{Cr}$ pada menit ke-15 sebesar $8 \%$ dan TDS sebesar $31 \%$ sedangkan penurunan $\mathrm{Ag}$ paling tinggi pada menit ke-75 sebesar 24\%, (3) Kualitas limbah cair setelah diadsopsi mempunyai kadar Ag 0,71 $\mathrm{mg} / \mathrm{L}, \mathrm{Cr} 1,12 \mathrm{mg} / \mathrm{L}$, TDS $15.400 \mathrm{mg} / \mathrm{L}$ dan $\mathrm{pH}$ 1,52 dan air limbah belum memenuhi baku mutu sesuai Peraturan Menteri Lingkungan Hidup No. 5 tahun 2014

\section{UCAPAN TERIMA KASIH}

Peneliti ucapkan terima kasih kepada UNIPA Surabaya melalui Lembaga Penelitian dan Pengabdian Masyarakat yang telah membiayai penelitian ini melalui Penelitian Unggulan Hibah Adi Buana tahun anggaran 2016.

\section{DAFTAR PUSTAKA}

Asbahani. (2013). Pemanfaatan Limbah Ampas Tebu Sebagai Karbon Aktif Untuk Menurunkan Kadar Besi Pada Air Sumur. Jurnal Teknik Sipil Untan, 13 (1), 105-114.

Collin G.J., Fauziah A.A., Hasnul F.M.Z. dan Siti F.D. 2006. Treatment of ldanfill leachate in Kayu Madang, Sabah: Porosity dan adsorption studies (Part 2). Asian Chemistry Letters, 10 (3-4), 89-94

Handayani, D.S., dkk. (2012). Adsobsi Ion logam Pb(II), Cd(II) dan $\mathrm{Cr}(\mathrm{III})$ oleh Poli 5 Allil Kaliks(4) Arena Tetraester. J Manusia dan Lingkungan, 3(19), 218-225.

Hartini, Eko dan Yuantari, MG.C. (2011). Pengolahan Air Limbah Laboratorium Dengan Menggunakan Koagulan Alum Sulfat dan Poly alum Chlorida Di laboratorium Kesehatan Universitas Dian Nuswanoto Semarang. Jurnal Dian, 11(2), 150-159.

Mirwan, M. (2005). Daur ulang limbah hasil industri gula (ampas tebu/bagasse) dengan proses karbonisasi sebagai arang aktif. Jurnal Rekayasa Perencanaan, 1 (3).

Mizwar, A. dan Haryati. (2014). Aktivasi Kimia-Fisik Limbah Serutan Rotan Menjadi Karbon Aktif. Jurnal Purifikasi, 14(1), 82-89

Nurhayati, I., dan Sutrisno, J. (2014). Pemanfaatan limbah ampas tebu Sebagai Penyerap Logam Berat $\mathrm{Cu}$. Wahana, 63(2), 27- 32.

Nurhayati, I., dkk. (2015). Arang Aktif Ampas Tebu Sebagai Media Filtrasi Untuk Meningkatkan Kualitas Air Sumur Gali. Waktu, 13(2), 9-18.

Patil, B.S. dan Kulkarni, K.S. (2012). Development of high surface area activated carbon from waste material. International Journal of Advanced Engineering Research dan Studies, 1 (2), 109-113

Priadi, C.R., Anita, Sari, P.N., dan Moersidik, S.S. (2016). Adsorpsi Logam Seng Dan Timbal Pada Limbah Cair Industri Keramik Oleh Limbah Tanah Liat. Reaktor, 15(1), 10-19

Sari, I.P. dan Widiastuti, N. (2010). Adsorpsi Methylen Blue Dengan Abu Dasar PT. IPMOMI Proboliinggo Jawa Timur Dan Zeolit Berkarbon. Prosiding Kimia FMIPA ITS 
Indah Nurhayati, Joko Sutrisno, \& Mochamad Sofyan Zainudin : Pengaruh Konsentrasi Dan Waktu Aktivasi Terhadap Karakteristik Karbon Aktif Ampas Tebu Dan Fungsinya Sebagai Adsorben Pada Limbah Cair Laboratorium

Surest, A.H., Permana I., Wibisono, R.G. (2010). Pembuatan Karbon Aktif Dari Cangkang Biji Ketapang. Jurnal Teknik Kimia Universitas Sriwijaya, 17(4).

Verla, A.W., Horsfall, M., Verla, E.N., Spiff, A.I. dan Ekpete, O.A. (2012). Preparation dan characterization of activated carbon from fluted pumpkin (Telfairia occidentalis hook.f) seed shell. Asian Journal of Natural dan Applied Sciences, 1 (3), 39-50.

Widayanti, Isa I., Aman, L.O. (2012). Studi Daya Aktivasi Arang Sekama Padi Pada Proses Adsorpsi Logam Cd. Jurnal Sainstek, 6(5), 488-494

Yuan, L. and Liu, Y., (2013), Removal of Pb (II) and Zn (II) from Aqueous Solution by Ceramisite Prepared by Sintering Bentonite, Iron Powder and Activated Carbon. Chemical Engineering Journal, 215-216, pp.432-439. 